В. В. Яшкіна

В.В. Яшкина

V.V. Yashkina

Дніпровський нащіональній університет імені Олеся Гончара

Днепровский национальный университет имени Олеся Гончара

Oles Honchar Dnipro National University

\title{
IMAGERY CREATED AND REFLECTED IN MULTILINGUAL POETIC TRANSLATIONS
}

\author{
ОБРАЗНІСТЬ СТВОРЕНА ТА ВІДТВОРЕНА В \\ МУЛЬТИЛІНГВАЛЬНИХ ПОЕТИЧНИХ ПЕРЕКЛАДАХ
}

\author{
ОБРАЗНОСТЬ СОЗДАННАЯ И ВОССОЗДАННАЯ В \\ МУЛЬТИЛИНГВАЛЬНИХ ПОЕТИЧЕСКИХ ПЕРЕВОДАХ
}

Питання про вдалу спробу перекладу поетичного твору, поряд із проблемою можливості існування адекватного перекладу художнього зразка в цілому, завжди було і залишається актуальним, оскільки досі не отримало остаточного вирішення. Лінгвісти наголошують на вагомих втратах, яких зазнають концептуальна, семантична і мовна сфери оригінального тексту під час його перекладу іншими мовами. Аматори i професіонали час від часу задаються питанням про дилему «еквівалентність або адекватність». Фахівці пропонують різні варіанти перекладів одного й того ж самого поетичного зразка, намагаючись досягнути максимального збереження його краси та змісту. В результаті стає цілком очевидним, що чим більш складним с оригінальний текст, тим важчим с відтворення його оригінального задуму.

В запропонованій статті розглядається питання про шляхи досягнення адекватності/еквівалентності поетичного тексту в мультилінгвальному перекладі. Вивчаються можливості подолання розбіжностей між оригіналом i перекладом, потенційна відсутність яких стає тим помітнішою, чим більшою кількістю мов перекладено поетичний художній твір.

Актуальність публікації вбачасться у тому, що всупереч певному ступеню вивченості проблеми адекватності/еквівалентності перекладу поетичного твору щодо його змісту та форми, проблема порівняння багатомовної спадщини відомого зразка ще майже не порушувалась.

Ключові слова: поезія, адекватність, еквівалентність, рівні існування поетичного твору, семантика, розбіжності.

Вопрос создания удачного перевода поэтического текста, наряду с проблемой возможности существования адекватного перевода художественного текста как такового, всегда было и остается актуальным, поскольку на сегодняшний день не получил окончательного разрешения. Лингвисты настаивают на существенных потерях, которые возникают в концептуальной, семантической и языковой сферах оригинального текста в процессе его перевода на другие языки. Специалисты и просто любители художественного слова снова и снова задаются вопросом: «эквивалентность или адекватность»? Профессиональные переводчики предлагают различные варианты переводов одного и того же произведения, стремясь максимально сохранить его 
красоту и содержание. В результате стает вполне очевидно, что чем более сложным выступает оригинал, тем сложнее передать его оригинальный посыл.

Изучается вопрос достижения переводческой адекватности/эквивалентности поэтического текста в мультилингвальном переводе. Рассматриваются возможности преодоления концептуальных различий между оригиналом и переводом, потенциальное отсутствие которых тем заметнее, чем на большее количество языков переведено произведение.

Актуальность публикации видится в том, не смотря на определенный уровень изученности проблемы адекватности/эквивалентности перевода поэтического произведения в плане его содержания и формы, вопрос сравнения его многоязыковых вариантов практически не поднимался.

Ключевые слова: поэзия, адекватность, эквивалентность, уровни существования поэтического произведения, семантика, расхождения.

Successful poetic text translation, as well as its entire possibility, has been of current relevance since the appearance of translations as they are, but have not received final solving. Linguists are proving failures of full conceptual, semantic and language preservation of the original in its translation. Both professionals and amateurs never stop arguing on the dilemma of equivalence versus adequacy. Translators offer numerous variants of one and the same poetic masterpiece with the aim of achieving maximum original beauty and sense. As a result, it becomes obvious, that the more different language translation samples appear, the better the original message of a poem is restored.

In given article we concentrated our attention on multilingual translations of the original poems poems, specifically comparing grammar, lexical, phonetic and strophe-building translation variants and discussing discrepancies between the original and its Romanic and Slavic translations. The main aim lies in an attempt to prove that multilingual translation practice serves as a source for translation variants to add to each other or open different aspects of the original, and, possibly, to achieve perfect revealing of a poetic masterpiece.

It has been proved by the research, that noncoincidence of certain translation equivalents accompanied by full correspondence of others, results in definite semantic loss. This fact underlines urgency of multilingual translations as means of achieving as full poetic texts comprehension as it is possible in other languages.

Key words: poetry, adequacy, equivalence, poetic text levels of existence, semantics, discrepancies.

The issue of a literary texts translation is not a new one. It goes back to the times of Ancient Rome when Cicero stated, that while translating one ought to "weigh" the words, but not to "count" them [8]. It seems to be one of the first attempts to solve the problem of adequacy versus equivalence. In the early feudal France the practice of translating tales of chivalry was very extensive, and served as a noble example, especially for literary communication with less developed neighboring cultures [8]. Later history of translation practice knows examples of specific areas, which rise under the influence of economic and political issues. In this framework the $19^{\text {th }}$ century was marked by wide practice of Oriental literature translations [8]. 
Theory of translation as a discipline started forming in the second half of the last century, and got reflection in the works of such well-known linguists as L. Barchudarov, V. Komissarov, S.Honcharenko, I. Alekseeva and others. But the first attempts to outline the main problems were already done much earlier. The statement about the fact, that among all literary works poetic masterpieces are more difficult from the translational point of view then prose, because they demand sharp feeling for language, inborn linguistic talent, and, certainly, high level of professional training were done by Vasiliy Zhukovsky. He reflected: "In poetry a translator is a contestant, but in prose he becomes a slave" [2, c. 15]. Putting this observation on theoretical grounds, Leonid Barchudarov wrote: "Means and ways of achieving poetic texts adequacy build up the most disputable issue in the theory of literary texts translation. Tight restrictions, arising from poetic texts specificity, make this genre challenging for translators" [1, c. 41].

Current relevance of high quality translation goes beyond doubts nowadays. Besides all other reasons, this fact is explained by rapid growth of multicultural strategies accompanied by bilinguism and multilinguism. Comprehension of a literary text, especially a poetic one, is under vivid influence of differences between cultures, national traits, customs and traditions. It means that poetry translation is under constant risk of disagreement with the original. Thus, the task of a translator in this case is to imbue his mind with high level of semantic load, and restore all depths of a foreign language masterpiece. Moreover, a demanding reader has long become unsatisfied with a general outline of the plot, having in mind the idea of full comprehension of all the original ideostylistic shades.

In this article we focused on multilingual translations of Seamus Heaney's selected poems, paying special attention to grammar, lexical, phonetic and strophebuilding discrepancies between the original and its Spanish, Ukrainian and Russian translations. The main aim lies in an attempt to prove that multilingual translation practice serves as a source for translation variants to add to each other or open different aspects of the original, and, possibly, to achieve perfect revealing of a poetic masterpiece. 
A prominent $\mathrm{XX}$ century translator Mikhail Lozinsky added, that while translating poetry, specialist should take into consideration all its elements in their complete difficulty and divergence [3, c. 68]. The ultimate task of a translator is to find among the means of translation language those adequately complex, sophisticated, and living connections, which exist between all poetic "mechanisms".

Nowadays the problem of high-grade literary translation is widely discussed not only by the post-Soviet linguistics, but also in foreign philological spaces. Debates now and again underline versatile character and inexhaustibility of translation practices, because the issue of possibilities and potentials of literary translations occupies a significant part in the framework of contemporary theory of translation.

Poetic text organization is so specific that translators work under vivid restrictions. It has been proved experimentally (V. Koller) that metaphorical character - one of the main peculiarities of art which is more inherent in poetry then in prose is half as lost in translation. Ostensible differences in structural and typological peculiarities of those languages which take part in the process of communication leave their mark on possibilities of preserving such main components of the original, as unities of form and plot, sound and semantics, intonation and rhythm. What is more, poetic speech does not endure rearrangements or reforms, because its word order, meaningful "tightness" of a poetic line, and sound semantics are united in an additional artistic function of sense-loading.

Working with poetry, a translator firstly addresses his effort to general denotative (referential) information reproduction. The second level of translation presupposes restoration of stylistic-connotative (pragmatic) meanings. This step is the most demanding one, as its essence lies in transition of national specificity, subtexts, inner linguistic meanings and lexical semantic peculiarities, rhyme, sound instrumentation, morphemic strictures and so on. It means that in practice lexical equivalence of two texts does not always maintain translational adequacy.

Structural and typological differences of alien languages become evident in the process of poetry translation, when "content, imagery, intonation, melody - 
everything is tightly bound to rhythmic, stylistical, strophic systems, and to each other" [4, c. 67].

Besides that, divergence of grammatical forms, though accompanied by lexical coincidence, may result in "from the original to translation" differences. This discrepancy becomes even more evident when we compare the poetic source with its multilingual translations. Nonrelevant character of Slavic grammar tenses results in certain boundedness of Ukrainian and Russian translations in comparison with the Spanish one. It appears that the possibility of accurate time line holding is maintained only in the language of the Romanic group which has similar tenses structure (in our case Past Continuous - Pasado Continius).

The original: "Where he was digging" (S. Heaney, "Digging”). Spanish translation: "Donde estaba cavando" (Н. Arguero). Ukrainian translation: "Де він копав” (I. Syvak), “Де йому копати” (O. Mokrovolsky). Russian translation: “Bom так же он картошку копал” (G. Krouzhkov).

Grammatical peculiarity of Heaney's idea lies in the necessity to prolong the action of digging here, as it is metaphorically connected with other occasions of this participle in the poem. In other words, from the point of view of semantics, Past Continuous tense in is bound to certain temporary action. But Ukrainian and Russian languages do not have instruments for adequate translation of the phrase "he was digging", thus these variants partly lack corresponding sense-loading function. Evidently, in Slavic translational variants the length of the digging process might have been conveyed lexically, but this attempt could have been at risk to create odd to the original senses. On these grounds the translators use either infinitive or Simple Past forms.

Simultaneously, noncoincidence of grammatical phenomena in different languages opens possibilities for generalization and universalization of events. As it was mentioned above, digging bears not only grammatical, but also semantic function: repeated three times throughout the poem in different temporal contexts, this structural element indicates unity of past and future via present: "When the spade sinks into gravelly ground: / My father, digging. I look down / <... “; "Stooping in 
rhythm through potato drills / Where he was digging. <...> "; "Over his shoulder, going down and down / For the good turf. Digging." Spanish translation demonstrates adequate triple use of one and the same verbal form - "cavando". Unlike H.Arguero, Ukrainian translators find versatile tense equivalents: "кonaє" “копати" - "накопати" (O.Mokrovolsky), "копае" - "копав" - “копаючи" (I. Syvak). As it can be observed, the essence of the process is kept, while semantics is preserved partly.

One of the most difficult tasks for translators lies in lexical dimension of words, because in one language this potential could be wider in comparison with equivalents in other languages. Or else, words may correspond in their main meaning, but be different in connotation, stylistics or peripheral shades. This discrepancy could eliminate secret sense of poetry [3, c. 95], the mystery which is largely lost in wordfor-word translation. Thus, theoretically translation of poetry should not be literal, otherwise it is possible for only the general content to be preserved.

But translation practice knows the examples of word-for-word translations, which are more successful than any other artistic attempts. On these grounds literary translation may sometimes be slightly different from, or completely coincide with the original, because translator uses the rule of "clearing up". For example, according to common principles, proper names do not undergo translation, only transliteration, though this happens not in any case.

The original: "Miss Walls would tell us how / The daddy frog was called a bullfrog”, (S. Heaney, "D.N.”). Spanish translation: "A senhorita Parede <...>” (H. Arguero),

Ukrainian translation: “Міс Волс якось розповідала <...>” (O. Mokrovolsky)

As we can observe, O. Mokrovolsky fully resorts to the transliteration principle (by the way, the same strategy is used in the Russian translation by G. Krouzhkov), but H.Arguero falls back on word-for-word translation. It might have been considered as an over-literal rendering, but for one detail. The name of a teacher in the poem is only the top of a deep meaningful context, which is at risk to be lost in translation. Comprehensive school Biology classes, conducted by Miss Walls, became a starting 
point for young poet on his way to the knowledge of the world. The iceberg-like meaning of the poem manifests, that teacher's surname, chosen by S. Heaney, is not an occasional one, because "the wall", which protects childhood, is to be destroyed soon by adult life. Metaphorical character of the name, so important to full understanding of the author's message, is restored only by H. Arguero ("Parede" means "railing"), who, evading the rules, translated proper name, when others are more academic, though less penetrating.

Another not less meaningful aspect of poetic works translation is sound instrumentation of the original. The problem is that phonemes, when separated from poetic sense, bear no poetry, only strict language potential. It is the poet, who artistically comprehends, masterfully treats and deliberately chooses sounds. And it is because of him mere verses become poetry which sings with alliteration, assonance, euphony. Poetic text sound instrumentation is inseparable from its semantics, which makes a poem almost impossible to be fully restored in translation.

Seamus Heaney, a poet with incomparable imagination and language, is a master of iridescent pictures. His inimitable sound "drawings" may combine in one poetic line the sinning of nature, or unite in authentic rhyme and melody the sounds of universe.

The majority of Heaney's poems are written in vers libre which does not demand rhymed line endings, but extensively uses inner rhymes based on sound instrumentations: "scut" - "scat", "splitter"- "splatter", "smelted emerald", "fossilbrittle", "rattle-skinned" and so on. With the help of sounding Heaney creates whisper of spring rains, the drops of which meet resilient young leaves: "For the splitter-splatter...", or cold ringing of delicate frost-covered branches: "For the scut and scat...", "fossil-brittle". The poet is very attentive and careful about any movement of nature, which he gathers in one picture of all-season tree.

The problem of sound repetition, which is equal to the problem of poetry existence, in this case, is the most successfully solved in the Russian language translation by G.Starikovsky. The translator skillfully chooses the consonants, though a bit sharp and more energetic, but not less poetic then those of Heaney's. With 
[sp/st] and [r] sings April shower and hibernated tree in translation: "Ради росплеска капель”, “Пусть растреплются кудри!"

Returning to Heaney's rhyme and metric composition in poetry we should note, that sometimes free verse leaves its place for more traditional genres like iambus or anapestic tetrameter. This fact is meaningful as rhyme suggests special accent of the poem, but from the point of view on translation it brings additional difficulties. Definitely, Heaney's poetry is so polyphonic, and his words are so polysemantic, that translator faces the dilemma, whether to preserve meaningful contexts or rhyme. And again, multilingual translations show, that one variant does not have potential to reconstruct all details.

The original: "Under my window, a clean rasping sound/ When the spade sinks into gravelly ground: “ (S. Heaney, "Digging”). Spanish translation: "Bajo mi ventana, un sonido de rascar limpio/ cuando la pala se hunde en el suelo de grava:". Ukrainian translations: "По-під вікнами чути різке скреготіння/ Лопати, що входить в землю, черкаючи об каміння” (I.Syvak), “А під вікном моїм лопата-зуб скрегоче:/Грунт кам'янистий піддається неохоче." (O. Mokrovolsky). Russian translation: "За окном - резкий, скрежещущий звук/ Лопаты о смешанный с гравием грунт” (G. Krouzhkov).

As it can be observed, two first lines of the original are rhymed in an adjacent way: "sound" - "ground"). This important detail is not left beyond Ukrainian translators' attention: “скрегоче" - "неохоче" and "скреготіння" - "об каміння". What is more, O.Mokrovolsky and I. Syvak masterfully render sound symbolism so important for Heaney, and also convey the idea of labor as a tribal tradition. Spanish translator, unlike in the case of grammar tense preserving, appears to be unable to restore rhyme and content simultaneously.

To make certain conclusions we should say, that theoretically, poetic work maximum translation equivalence is achieved when main pragmatic, stylistic, and semantic aspects of it have been reflected. In practice none of the poetic texts integral components, which have been translated equivalently, may guarantee artistic unity and uniqueness. Lexical equivalence is not a full insurance of the original-translation 
adequacy. As it has been proved, noncoincidence in grammatical forms along with full lexical correspondence, results in definite semantic loss. Sound symbolism appears to be the most relevant for potential equivalence, and this fact proves the translators' mastery. All this considered together underlines urgency of multilingual translations as means of achieving as full poetic texts comprehension as it is possible in other languages.

\section{References:}

1. Бархударов Л.С. Тетради переводчика / Под. ред. Л.С. Бархударова. - М. : Международные отношения, 1964. - 142 с.

2. Левин Ю.Д. Русские переводчики XIX и развитие художественного перевода / Ю.Д.Левин. - Л. : Наука, 1985. - С. 15-18.

3. Николаев, В.Д. Михаил Лозинский. К 120-летию со дня рождения / В.Д. Николаев // «Мир перевода». - № 1(15), 2006.[1]. - С. 37-38.

4. Сухарев-Мурышкин, С.Л. Некоторые особенности строфического стиха и стихотворный перевод / С.Л. Сухарев- Мурышкин // Сборник научных работ. - Л., 1977. - 312c.

5. Folkart, B. Translation and Arrow of Time / B. Folkart // "TTR: Studies in the Text and its Translations”. - Bristol, 1989. - Vol. 2, № 1. - 148 p.

6. Heaney, S. Selected Poems / S. Heaney. - L.: Penguin, 2000. - 362 p.

7. Miron, M. S. A cross-linguistic investigation of phonetic symbolism / M. S. Miron / J.: Abnormal soc. Psychol., 1961. - 73 p.

8. Практическая транскрипция как метод передачи имен собственных // Энциклопедия переводчика. - Режим доступа: http://www.trworkshop.net 